\title{
“Why Don't You Just Say It as Simply as That?": The Progression of Parrhesia in the Early Novels of Joseph Heller
}

\section{Peter Templeton}

\section{(2) OpenEdition \\ Journals}

Electronic version

URL: https://journals.openedition.org/ejas/11573

DOI: $10.4000 /$ ejas. 11573

ISSN: 1991-9336

Publisher

European Association for American Studies

Electronic reference

Peter Templeton, "'Why Don't You Just Say It as Simply as That?": The Progression of Parrhesia in the Early Novels of Joseph Heller", European journal of American studies [Online], 11-2 | 2016, document 6, Online since 11 August 2016, connection on 08 July 2021. URL: http://journals.openedition.org/ejas/ 11573 ; DOI: https://doi.org/10.4000/ejas. 11573

This text was automatically generated on 8 July 2021.

Creative Commons License 


\title{
"Why Don't You Just Say It as Simply as That?": The Progression of Parrhesia in the Early Novels of Joseph Heller
}

\author{
Peter Templeton
}

1 The critical placing of Joseph Heller (1923-1999) has long been underdeveloped, likely as a result of the dominance of Catch-22 (1961). As George J. Searles suggested in 1977, Heller was often dismissed as "simply another example of that peculiarly American literary phenomenon, the 'one book' author" (74). Despite the five Heller novels that followed the publication of Searles' article, Catch-22 has seemingly continued to pull the vast majority of critical attention towards it and, consequently, the wider perception of Heller's early novels has been somewhat neglected. When focus has progressed beyond Yossarian and the island of Pianosa to Heller's other two early novels (Something Happened [1974] and Good as Gold [1979]), there is a tendency to place his work primarily in ethnic terms, as in the work of Frederick C. Stern (who identified that after the publication of Something Happened, the tendency was to see Heller's characters as Jewish) andWayne C. Miller. This folds Heller into a larger group of Jewish-American authors writing roughly contemporaneously, including Bernard Malamud, Saul Bellow, and perhaps the voice that now dominates such discussions, Philip Roth. However, Stern also suggests that "another category into which Heller fit was that of 'dark humorist"' (15). This has been echoed in more recent criticism which has equated Heller with the then-growing trend of black humor that dealt with taboo subjects by "comedians like Elaine May and Mike Nichols, Mort Sahl, and Lenny Bruce" (Fermaglich 61), a direction which might also be seen as re-inscribing Heller's Jewishness, given the ethnic background of each member of this group.

2 This emphasis, not just on ethnicity or on comedy but on that need to probe into subjects considered off-limits by mainstream American society during the 1960s and 1970s, may provide us with the beginning of a more satisfying critical placing for 
Heller. While the desire of some critics to move back through the catalogue of Heller's work and begin to understand the important Catch-22 as more Jewish than anyoneperhaps even the author himself-had imagined is completely understandable, if we wish to go further and attempt an understanding of the early-Heller oeuvre more widely, then we must consider the recurring features of his work: Heller's status as a humorist and the bitter tone of his comedy, as well as his repeated railing against ruling figures and organizations. It is this repeated focus on the public sphere, rather than the more intimate spaces afforded by the self or the family, that means a biographical or ethnic approach to Heller's work will always be less than fully satisfying. It is imperative, then, that we focus on "the double binds, the catch-22s, the entrapments variously represented in Heller's fiction by military regulations, corporate bureaucracies, or political machines" (Pinsker 2).

3 It is when thinking about Heller's repeated returns to the organizational structures that bind us that the later work of Michel Foucault can be instructive. Fearless Speech, published in 2001 by Semiotext(e), "was compiled from tape-recordings made of six lectures delivered, in English, by Michel Foucault at the University of California at Berkeley in the fall term of 1983" (Pearson 7). The work deals with the topic of parrhesia which "is ordinarily translated into English by 'free speech"' (Fearless Speech 11). Foucault explores the original Greek concept of parrhesia at some length in terms of its first proponents, the Cynics:

For the Cynics, the main condition for human happiness is autarkeia, self-sufficiency or independence, ... consequently, most of their preaching seems to have been directed against social institutions, the arbitrariness of rules of law, and any sort of life-style that was dependent upon such institutions or laws. In short, their preaching was against all social institutions insofar as such institutions hindered one's freedom and independence. (Fearless Speech 120)

Significantly, Foucault intimated in an interview with Pierre Boncenne in 1978 that "the analyses that were current during the 1960s defined power in terms of prohibition: power, it was said, is what prohibits, what prevents people doing something" (Politics, Philosophy, Culture 102) Foucault would of course disagree with this assessment of power as prohibitive, given that he states elsewhere that power "is not the renunciation of freedom," but his comments refer to a conception of power very much current in the cultural milieu in which Heller's early novels were drafted and published (Essential Works 340). Heller likely became one of the chosen authors of the card-carrying anti-authoritarians of this period precisely because of this rather limited attitude towards organizational or political power.

5 At a thematic level, then, it is not difficult to draw a comparison between the restrictive notions of power that were prevalent in countercultural philosophies of the post-war US, such as the movement against the war in Vietnam, and the parrhesia of the Greek Cynics. In his lectures that became the book Fearless Speech, Foucault argues that even in the modern era, "Preaching is still one of the main forms of truth-telling practiced in our society, and it involves the idea that the truth must be told and taught not only to the best members of the society, or to an exclusive group, but to everyone" (120). This notion of preaching as a kind of democratic oratory from the heart of ancient Greece seems to underpin if not Heller's authorial intentions (though this perhaps comes more to the fore in aspects of his 1988 novel, Picture This), then at least his inclinations, when confronted by the social and political practice of post-war America. 
6 The thematic comparisons between the two, however, do not address the question of stylistics, which one might see as the greatest obstacle to equating Heller with a form of parrhesia. If the term applies to the most direct form of speech available, then the kind of linguistic game-playing that we encounter in Heller's novels might seem to situate him rather differently, as much more of a rhetorician than a straightforward preacher. And, indeed, I would not want to argue that Heller is not a writer who is well versed in irony. Rather, this article suggests that Heller's early novels develop from an ironic mode and the levels of linguistic and allegorical complexity are stripped away until Heller enters the realm of parrhesia. I would also stress, however, that by reading Heller's development in the light of parrhesia some of the distinctive strands of his unique brand of irony might also be thrown into greater relief.

7 Though Heller's novels depend heavily on situational irony he writes very differently from some other authors. Though each is devastating in its own way, Heller's irony is often deployed as something of a blunt instrument. This is not to say that his writing lacks skill or finesse, so much as it is a statement on effect: one is far less likely to miss the underlying message of Heller than with many other practitioners of irony. Indeed, each of his early novels might well be called a polemic, with each taking aim at various American institutions. He speaks out against, for example, the corporate world, potentially in Catch-22 and more explicitly in Something Happened. In this development, we can see Heller progressing towards far more plain speech: though each novel provides a criticism of American corporations and each is heavily dependent upon a strong ironic style, the subject is addressed directly in the latter novel rather than being realized through allegory. His vitriol appears in its most concentrated form in patches of his third novel when, during the poisonous political climate of the 1970s, he critiques American political institutions-and Henry Kissinger in particular-in Good as Gold, in which moments Heller's style gives way to pure parrhesia. This attitude is visible early in his development as a novelist; a reviewer of Catch-22, before it became the canonical work it is today, complained that it "gives the impression of having been shouted onto paper" (Balliett 247).

8 The most telling reason that we must see Catch-22 as a novel that is addressing the post-war American condition, rather than merely a belated reaction to his time in the USAF, is the number of times in which the novel satirizes American culture of the 1950s. One of the most obvious examples of this is Heller's condemnation of McCarthyism, demonstrated through the character of Captain Black. Typically, Heller is less than subtle when he writes that "Captain Black knew he was a subversive because he wore eyeglasses and used words like panacea and utopia, and because he disapproved of Adolf Hitler, who had done such a great job of fighting un-American activities in Germany" (Catch-22 42). Here, the novel is still operating very much within the limits of situational irony, as an American officer during the Second World War admiring Hitler clearly contradicts our expectations. There is, however, more happening here; the phrase "un-American activities" immediately recalls Joseph McCarthy and his influence on post-war American politics. The character of Captain Black mirrors McCarthy as the novel progresses, as he sets up the institution of loyalty pledging:

At the far end of the food counter, a group of men who had arrived earlier were pledging allegiance to the flag, with trays of food balanced in one hand, in order to be allowed to take seats at the table. Already at the tables, a group that had arrived still earlier was singing 'the star spangled banner' in order that they might use the salt and pepper and ketchup there. (Catch-22 128) 
In this vignette, Heller has created a world in which one must demonstrate patriotic feeling in order to receive even the most basic rights. Though an exaggeration, McCarthy is recognizable here, as is Executive order 9835, "which established federal loyalty review boards, [and] legitimated subsequent 'loyalty' investigations of employees across the land, local and state as well as federal, private as well as public" (Fried 28). We might focus here on the weighty significance of the word "loyalty" or the strong nationalist bias on display, but equally clear is the agenda of such procedures, which is shown through the attitudes of the investigators in the trial of Clevinger. This is revealed to be clearly not justice, but a rabid, monomaniacal attempt to identify threats to the American system, much as the actual loyalty investigations sought to root out communist sympathizers. Heller composes the scene so that the board investigates Clevinger, a character as supportive of the ideals of the authorities as any character in the novel, to make an additional point. If someone like Clevinger can be tried for un-American activities, then anyone is vulnerable to such charges. Rather poignantly, it is the patriotic Clevinger who is the last to fully grasp the situation:

It was all very confusing to Clevinger. There were many strange things taking place, but the strangest of all, to Clevinger, was the hatred, the brutal, uncloaked, inexorable hatred of the members of the Action Board, glazing their unforgiving expressions with a hard, vindictive surface, glowing in their narrowed eyes malignantly like inextinguishable coals. Clevinger was stunned to discover it. They would have lynched him if they could. (Catch-22 92)

10 At this moment, we can see that Heller is not employing irony in the way that he does elsewhere in the novel. Though he has not yet reached the level of pure, direct speech we would associate with parrhesia, his intention is to highlight the underlying injustices of McCarthyism. The hatred shown by the Board ensures that an accusation is as good as a conviction. In an interview in 1974 Heller described McCarthyism as "misuse of the FBI, the CIA, misuse of the courts, the attorney general's office, and so forth. Political persecutions" (Sorkin 119). In the early years of the Cold War, people were terrified to criticize accepted positions and scared into submission by such authoritarian policies. This is a particularly extreme example of what Foucault called governmentality, one of the functions of which is that we police our own behavior rather than having the agents of the state fulfill that role. It is only the consent of the governed that separates this from more deliberately coercive or repressive associations. But Heller's fiction suggests strongly that the consent has been undermined through scare tactics, and that agencies of the state designed to protect the citizenry have, in fact, been twisted against them. Thomas L. Dumm writes of Foucault's work, and the same can be applied to Heller here, that "it served as a harsh repudiation of the pieties of so many who thought that their own political motives are pure, by demonstrating the ways in which the premises of their political commitments themselves operate as means of domination" (10). The obvious parallels with McCarthyism offer some of the most compelling evidence for reading the novel as a wider satire on public life (be that corporate or political through the 1950s), and it is here that Leah Garrett's (admittedly compelling) case for Yossarian's Jewishness does have to give way to some of the other, more prominent readings that she mentions in her recent article: though the barbs aimed at Yossarian by Colonel Cathcart "such as 'suspicious' and 'socialist'... are typical slurs against Jewish Americans," the strand of the novel involving Captain Black, added to all other evidence, suggests that Yossarian as a more universal "stand in for all those 
who have been victimized by McCarthyism" will resonate more clearly with most readers (Garrett 397).

11 Fear is not the only way of using power to control people that Heller rails against; his novels routinely feature an unnavigable bureaucracy or overly complex administration. On bureaucracy, Paul Du Gay has written that in today's world, "the bureau carries a very hefty 'charge sheet,' inscribed with multiple offences ranging from the relatively banal-procrastination, obfuscation, circumlocution and other typical products of a 'red tape' mentality-to the truly heinous-genocide, totalitarianism, despotism" (1). He also notes the inherent contradiction here, since clearly the bureaucrat cannot be both a bumbling, incompetent, lazy administrator and simultaneously a scheming, malevolent one who acquires power through endlessly circular legislation. One question to ask is whether Heller's presentation of bureaucracy follows the lines laid down by Du Gay, or whether it repeats the charges that he lists and is seen as a controlling and oppressive structure.

12It would be negligent not to begin with Catch-22, a novel whose title has entered the cultural lexicon as meaning a double bind, not least of all in the bureaucratic sense. As Foucault has observed, "relations of power, and hence the analysis that must be made of them, necessarily extend beyond the limits of the state" (Essential Works 120). Military bodies are not only fighting forces: they also exist as large administrative bureaucracies, and it is in those moments of Catch-22 when the focus shifts towards hierarchical arrangements or the business world that the military becomes an allegory for bureaucratic structures in post-war American civilian life, such as in the control that Milo Minderbinder is able to exert over the military hierarchy due to the success of his dubious enterprises. As Martin Albrow summarizes Max Weber, the sociologist and most important theorist of bureaucracy, "The modern army officer, the Roman Catholic bishop, the factory manager were all officials also, spending much of their time in their offices interpreting and transmitting written instructions" (41-42). In this framework, the modern army or air force officer is essentially a bureaucrat. Other American soldier-writers, such as John Dos Passos in Three Soldiers (1921) and Norman Mailer in The Naked and the Dead (1948), had already tended to take aim at the administrative controls placed on soldiers and their movements as much or more than they had focused on the horrors of actively pursuing war itself. Following the criteria laid down by Weber, it is easy to draw a comparison between his conception of the official's role and a number of characters in Catch-22. The group commander Colonel Cathcart is a bureaucrat responsible for the administration of lower ranks, and his presentation alludes not only to the fear of the prejudiced and vengeful official who uses his or her role for their own gain, but to the harmful effects of the bureaucrat at a remove from the work that they administer. Cathcart's power stems from his control the assignment of missions, yet he admits sheepishly to Milo Minderbinder that he has flown just four missions. Comically, Milo replies to this: "It's generally known that you've flown only two missions. And that one of those occurred when Aarfy accidentally flew you over enemy territory while navigating you to Naples for a black market water cooler" (393).

13One of the problems with the contemporary bureaucratic situation has been articulated by Peter M. Blau and Marshall W. Meyer, who suggest that "the dependency of bureaucratic subordinates upon their immediate superior produced by his rating power engenders frustrations and anxieties for adults. It forces employees to worry 
about their supervisor's reaction at every step of the way" (66-67). This is evident in Cathcart's group, since in controlling who flies what mission he comes as near as possible to holding the power of life and death. Consequently, the men in his group fear his reactions because they affect their chances of survival. Heller explores the psychological effect of this at some length:

They were men who had finished their fifty missions. There were more of them now than when Yossarian had gone into the hospital, and they were still waiting. They worried and bit their nails. They were grotesque, like useless young men in a depression. They moved sideways, like crabs. They were waiting for the orders sending them home to safety to return from Twenty-seventh Air Force headquarters in Italy, and while they waited they had nothing to do but worry and bite their nails and find their way solemnly to Sergeant Towser several times a day to ask if the order sending them home to safety had come.

They were in a race and they knew it, because they knew from bitter experience that Colonel Cathcart might raise the number of missions again at any time. (Catch-22 34)

Heller's target is still the corporation in passages like this, with the focus clearly on organisational structures rather than the horrific aspects of fighting, but this allegory of the post-war corporation is intensified through the setting. The stakes here are clearly life and death. Cathcart is, in essence, buying his way to the rank of General with the lives of men such as Snowden, Clevinger and Nately.

15Blau and Meyer make reference to another problem within bureaucracy, this time relating to the idea of goal-oriented targets. They say that "a difficulty with these ratings systems is that they can encourage useless or careless work" (131). In Catch-22, this is made manifest in the ridiculous emphasis on bombing patterns. Cathcart becomes obsessed with this system, even remarking to the Chaplain that he "think[s] a tighter bomb pattern is something really worth praying for" (208).However, a later conversation reveals that General Peckem has merely invented the term without reason, with the added irony present in his observation that he has "all sorts of people convinced I think it's more important for the bombs to explode close to one another and make a neat aerial photograph. There's one colonel in Pianosa who's hardly concerned anymore with whether he hits the target or not" (345).

16 It has been noted by many critics that one of the things that make bureaucracy such a potent force in Catch-22, and which has helped the novel achieve its immense popularity despite its undeniably dark subject matter, is the ironic pseudo-logic that rests at the heart of the system. Yossarian and his comrades come to see that the logic which controls them is endlessly circular, and almost elegant in its brazenness. But though some eventually understand the controlling mechanisms, for much of the novel the overwhelming feeling is one of bewilderment, with events seeming to be dictated by chance rather than logic. Perhaps the most famous instance of this in Catch-22 sees the allegory extend to the increasing corporatization and computerization of post-War American life, reflected in the character of Major Major being promoted to the rank of Major by a glitch in the mechanics of the system. However, in true absurdist mode he is forced to assume this new role, and in a move that reveals the meaninglessness of the 
entire hierarchy he is a major before completing basic training. This will eventually lead to the exchange between Major Major and Lt. Scheisskopf in which the commanding officer is paradoxically outranked by his subordinate, and the two call each other "sir" a total of seven times in three sentences (99). The people who must operate within this system are kept at a remove from the underlying logic. A man can outrank his commanding officer and that will be accepted, because that which is written down will have precedence over any sensible protestations raised against it. The relationship between the two men is complicated, humorously in this instance, through a quirk of the system which keeps them both visibly off-balance.

17The official administrative record has primacy in Heller's novel, even over facts that might be considered blindingly obvious. This is most clear after McWatt's plane crashes. Doc Daneeka is incorrectly listed as a passenger on the plane, which leads to a character saying (presumably with a straight face): "The records show that you went up in McWatt's place to collect some flight time. You didn't come down in a parachute, so you must have been killed in the crash" (363). Bernard S. Silberman has written of bureaucracy that its "structural characteristics are seen as possessing a kind of allocative and relatively frictionless efficiency," but what we can see here is a bureaucracy that has become too efficient; it has become self-propagating to the point at which it pays no heed to the world that it is supposed to be recording (20). The paper is law to such a degree that, when Daneeka attempts to contest his status as a corpse, "Colonel Korn sent word through Major Danby that he would have Doc Daneeka cremated on the spot if he ever showed up at Group Headquarters" (365). As Pinsker says, "such is the long reach of death in a novel where bureaucracy is a more efficient killing machine than German bullets" (33).

18If Heller's fiction operates primarily as a social critique of the post-war US, this is often achieved by his utilization of characters who either operate on the margins of society, or those whose relationship with hegemonic forces is unstable or otherwise fraught. For Dan Beer, "The outsider represents a space where some freedom still exists. $\mathrm{S} /$ he has a symbolic importance as s/he defies power's universalizing ambitions, and reveals power's creations to be imposed inventions rather than necessary, natural or permanent formations" (111). When Heller's outsiders stand in contravention of various social organizations and hierarchies, their dissent exposes the tactics by which the latter act to constrain individuals. As David Seed says, "Yossarian's actions confirm Heller's assertion that he is 'innocent and good' by constantly asserting the simple truisms which a manic bureaucracy obscures" (30).If as readers we find that we root for Yossarian, it is because his moral structure is certain; unlike the unthinking but murderous Aarfy, Yossarian will never be seduced into thinking that the military crime of being off base without a pass-effectively nothing more than a bureaucratic restraint of liberty-is worse than murder.

19 Yossarian is a natural place to begin, not only because he is the protagonist of Heller's first novel, but also because he is the author's great rebel: the character who "engaged our sympathy by defining a morality for the absurd world and whose conclusion suggested an optimistic hope for escape" (Strehle 550). But we should not stop with Yossarian. In most of his later novels, Heller's principal characters still always seem to maintain some distance from, or discomfort with, the structures of their respective corporate and political arenas (the notable exception perhaps being King David in God Knows [1984], although even he is alienated at the point of narration). Even 
Bob Slocum-the central character in Heller's explicit excoriation of corporate America, Something Happened, and possibly the protagonist of Heller's we are least likely to sympathize with-has some redeeming features, and this double edge to his personality affects the formal elements of the novel since "the oxymorons in Slocum's style correspond to the contradictions in his behaviour. He simultaneously wants to succeed in his company and mocks that success" (Seed 121).A central character who embodies oxymorons seems to suggest that Heller's second novel will rely as heavily on ironic devices as his first, and indeed, there are some stylistic echoes of Catch-22 in Something Happened: but in this novel, Heller does not veil his criticism of post-war American corporate culture in allegory. The subject matter is addressed more directly, and the purpose of the irony remains similarly pointed.

20 Heller's protagonists often mock the illogic of established social systems, and they can stand at some critical distance from them, but they can never escape their power completely. As Foucault says, "a society without power relations can only be an abstraction" (Essential Works 343), and Yossarian, Slocum and Bruce Gold all exist within satirically enhanced but essentially recognizable American social environments. Though the world Heller presents is often exaggerated there is a recognizable world beyond the hyperbole. It is the power dynamics of their respective recognizable spheres that serve to squeeze and warp Heller's characters. This is most explicit in Something Happened, as the fear that Heller imagines to be inherent in the office environment of contemporary corporate America warps his central character and his view of the world. As Pinsker has noted, "no word is more charged, more fraught with psychic energy, more repeated, than fear" (61). This anxiety is instilled into its narrator, Bob Slocum, seemingly by everyone he meets. Also, though we cannot be certain due to the personal narration, it is strongly implied that Slocum is a source of fear to many others. Those who strive for success on the corporate ladder, like Slocum, are perfect embodiments of the self-policing nature of governmentality. Stern writes that

21The hell into which Bob Slocum (and, as it were, looking over his shoulder, Heller) looks is the corporate hell, the world in which money and security are acquired at the cost of constant, self-destroying, pervasive fear, the world of those 'inwardly breached by the incalculable warp of time and change', as lived in the penumbra of the corporate world. (10)

22It might seem unusual at first that a novel set in an American office would describe more explicit fear than one in which the protagonist is constantly obsessed with his death in battle, but the world of Something Happened is a warped one in which the inhabitants are kept off-balance and uncertain: so much so that they consume themselves from within. The entire novel, one described as "a redundant text, one in which clearly limited elements-characters, actions, words-are combined, recombined in probable ways, and even repeated," is brought into being through the focused repetition of this state of anxiety (LeClair 246). Pinsker suggests that "Slocum's unnamed company... is a study in benign neglect and organizational inertia" (46), but there is a strong impression that there is something much more malevolent about the presentation of the American workplace here. The first time we are introduced to the world of Slocum's office, we are confronted by the fear that exists there:

In the office where I work there are five people of whom I am afraid. Each of these five people is afraid of four people (excluding overlaps), for a total of twenty, and each of these twenty people is afraid of six people, making a total of one hundred 
and twenty people who are feared by at least one person. Each of these one hundred and twenty people is afraid of the other one hundred and nineteen, and all of these one hundred and forty five people are afraid of the twelve men at the top who helped found and build the company and now own and direct it. (Something Happened 19)

While the fear of those in a more privileged place in a hierarchy might be considered normal, and indeed not far removed from what we see in Catch-22, it becomes apparent as Something Happened progresses that the fear in this office space is not unidirectional. Slocum's boss, Jack Green, "is afraid of me because most of the work in my department is done for the Sales Department, which is more important than his department, and I am much closer to Andy Kagle and the other people in the Sales Department than he is" (22). What exists here is a corporation in which the higher echelons of management keep everyone in check through an intricate, implicit system of reciprocal fear. Graham Thompson says:

Interestingly, then, the institution of relationships of terror and fear between men in the office hierarchy operate in two directions at once. Not only are men who are subordinated in this hierarchy subject to fear from those above, but those above are also fearful-one might say paranoically so-of those below, since it is the men below who can ensure their 'obsolescence.' (113)

Middle management has authority over the lower orders of the company, and this cultivates a relationship of fear over their underlings. However, through corporate structuring anomalies (such as slocum doing most of his work for Kagle although he is in Green's department), the higher echelons are able to instill levels of fear within their middle management team, and create politics and divisions within that structure. These divisions lead in turn to mass paranoia, and suspicion of everyone that can influence your career, which in this office environment is everyone you encounter, both superior and inferior in rank to yourself. In an interview with Ann Waldron in 1975, Heller suggested that he modeled the company on Time because "I did not want to write a book about economic exploitation. I wanted a neutral corporation" (Sorkin 136). Heller clearly aims here to target a society which would use fear as a control mechanism, rather than the corporation generally or capitalism itself. However, the trouble with taking aim at this kind of society is that it is profoundly capitalist in nature, and is therefore devoted to both the reproduction of hierarchy and a destructive competitive ethos which, indeed, underlies the rationale for the use of fear in the first place.

25Power relations in middle-management seem to operate on the principle that knowledge is a weapon. In Something Happened, fear often stems from how information kept from a character might be used against them. Slocum admits that "I always feel very secure and very superior when I'm sitting inside someone's office with the door closed and other people, perhaps Kagle or Green or Brown, are doing all the worrying on the outside about what's going on inside" (58). Thompson remarks that "to be on the outside, then, induces fear and paranoia," and suggests that Slocum is only happy if the door is closed behind, rather than in front of him (117).There is a perceived safety inherent on being on the inside of a situation, while to be the outsider marks you out as one who has cause to be afraid. Comically, Slocum does not know, nor seem to care, which colleague fears him in this situation. All we know is that he wants to believe that someone is worried by his meeting in the way that he would be if the situation were reversed. Slocum has to feel as if he is intimidating others, or in a world of 
metaphorical kill-or-be-killed he will be insecure and intimidated himself. He seems to express regret, but undercuts this: "I don't ever really want to frighten any of them and am always sorry and disgusted with myself afterward when I do. Almost always. But only after I succeed in bullying them; if I try to bully them and fail, I am distraught. And frightened" (163-164).

26This last quotation, although it highlights exactly how Slocum feels about the use of coercion as a tool in the workplace, does not refer to his colleagues, and leads to possibly the most sinister element about the fear that dominates the corporate world in Something Happened. Stern argues that "Even sexual life within marriage, Slocum is telling us, is dominated by the money ethos. The only objective of corporate life-the making of money-creeps, indeed leaps, into the marriage bed" (24). It is unsurprising that at the root of much of the critique in Something Happened lies the transgression of the private sphere by the coercive and aggressive nature of business. This manifests itself in the novel through the infection of all of the connections in Slocum's life, since the corporate world stretches not just to his wife, but has seeped through and colors his relationships with his entire family.

27The desire to accumulate that is instilled by consumer capitalism is, by this point in time, so acute as to be total. Thompson suggests:

Part of the problem for Slocum here is the difficulty of moving between the spaces of work and home. Although the demands are different in each of these environments, Slocum struggles to switch from the demand that he act a certain way at work to the demand that he act a certain other way at home. Instead of relating to his wife and daughter as his wife and daughter, he treats them in the same way that he treats his colleagues at work, that is competitively and with suspicion. (120)

Slocum is programmed by his work, becoming an automaton that cannot shut down and act differently outside the office. This has consequences not just for the family, but for his relationships with friends, too. Slocum admits that he enjoys the misfortunes of friends "because he cannot condone their weakness" (Something Happened 135). He admits that once his mother is no longer of use to him she becomes a "dead record in [his] filing system," a metaphor that not only has corporate associations but recalls another American figure broken by his work, Herman Melville's Bartleby (108). Even his perception of his son, with whom he has the best relationship, is tainted by the logic of the corporation, since signs of weakness in his son conjure up thoughts of violence: "I wanted to kill him. I was enraged and disgusted with him for his helplessness and incompetence" (334). Slocum shows remorse for this initial feeling, but his first reaction is unadulterated hatred. He sees his son as a weakling, one who would not survive in the business world, and wants to kill him in much the same way that he wants to attack and excise other visible points of weakness, such as Andy Kagle's limping leg. This corporate influence on the family life of slocum can be analyzed with reference to Brian Massumi's work on everyday fear. Though Slocum is part of this system rather than a consumer, his condition is indicative of what Massumi describes as "ever present dangers blend[ing] together, barely distinguishable in their sheer numbers. Or, in their proximity to pleasure and intertwining with the necessary functions of body, self, family, economy, they blur into the friendly side of life" (10). The end result, including the seamless transfer of the fear evident in the corporate world to the domestic sphere, is that "Slocum's condition... gradually becomes a scathing, uncompromising portrait of contemporary life" (Pinsker 54). Put another 
way, if Yossarian is trapped by the army and by law, "Bob Slocum is most surely and instructively trapped in a mode of thinking in the language of that thinking" (LeClair 246). He is trapped by the logic of corporate America.

29Heller's third novel, Good as Gold, aims right at the heart of American administration and the political system of Washington D.C. Perhaps more significantly, however, it is this novel in which Heller will occasionally abandon some of the stylistic choices that he had used in his first two novels, such as ironic language and allegory, and lurch most strongly towards outright parrhesia. While Good as Gold was a profitable venture for Heller, securing a sizeable advance, it never achieved the kind of critical success that Catch-22 had, and took a beating from some critics. Anthony Fowles says of Heller's portrayal of Washington:

It seems absolutely incredible that, writing hard on the heels of Watergate, Heller should come up with such lame tomfoolery as this. Yes, there is acknowledgement of political 'spin' here. But there is no indication of the profound dangers of doublethink which Orwell is (just about) able to make real. (49)

However, this scathing attack does Heller something of a disservice. Pinsker's more moderate comments suggest that "it wasn't at all clear how its apparently disparate stories... merged into a satisfactory novel; nonetheless, there were whole scenes that struck Heller's fans as pure Heller, complete with the dark, absurdist humor and biting satiric energy that have been his trademarks" (64). If the novel works, it is as this polemical document, and to expect the myriad of other plot strands to cohere is to mistake Heller's work for something it is not. Heller may have been attempting to write a novel of Jewish-American experience in Good as Gold, but it is clear that the other many impulses at work are checked, and indeed engulfed, by the need to act as a commentator on the kind of political establishment in which someone like Kissinger can reach such eminence. Though it is true the novel is far from Heller's most complex in terms of narrative style or form, innovation and aesthetics are somewhat foregone in favor of a brutal condemnation of the bureaucratic and openly mendacious nature of Washington D.C., a city in which unelected partisan officials, chosen arbitrarily, hold far too much power. Consequently, there is an added level of directness about his parrhesia in certain sections of Good as Gold. When the job of Secretary of State is dangled in front of Gold and he raises his lack of experience, the objection is brushed away by Ralph Newsome with the comment: "That's never made a difference" (Good as Gold 60).

31Here, Washington is full of wasteful, self-serving officials, with daily expenses of up to a thousand dollars. They also try and bamboozle at every turn. Like Catch-22, the bureaucracy Heller creates in Good as Gold is actively repressive, and is designed to subdue. Eva Elzioni-Halevy has said that 'bureaucracy is becoming more and more independent and powerful and the rules governing the exercise of that power are not clearly defined' (87); that is the aspect of administrative power that Heller targets.He exaggerates the flaws in systems to the point of absurdity in order to allow the reader to see where bureaucracy can go if it remains unchecked. Like Catch-22, all of this is accomplished through the power of language, and Heller's playful use of situational irony is evident once again. The character most associated with this kind of linguistic gymnastics in the novel is Ralph Newsome, whose language, according to Pinsker, is "designed to cancel itself out... in short, the slippery language of equivocation, endlessly flexible and designed to almost say what desperate people want to hear" (73). 
32 Good as Gold interrogates the more explicit complexities of American political bureaucracy. Elzioni-Halevy writes that since the age of Jefferson, "party service was considered as a legitimate prerequisite for appointment to office and party dissent as a cause for dismissal" (164). This perfectly describes the political establishment in Good as Gold. One of the most important attributes that makes Gold so appealing to the Washington elite is his ability and willingness to fit into the existing ideology and practice of the government: or, as Newsome puts it, "This President doesn't want yesmen. What we want are independent men of integrity who will agree with all our decisions after we make them. You'll be entirely on your own" (54). Here, Heller's meaning is once again completely evident beneath his rhetoric; he excoriates the procedure by which appointments of Washington officials are made, with aptitude unimportant compared with being of the 'correct' political persuasion.

33Though showing elements of parrhesia, the novel uses situational irony in much the same way as Catch-22. The picture of the President is so cynical as to be simultaneously hilarious and frightening:

'The President will be pleased I'm seeing you today, if he ever finds out. You sure do boggle his mind. He has a framed copy of your review of his My Year in the White House under the glass top of his desk in the Oval office so he can reread it all day long during vital conversations on agriculture, housing, money, starvation, health, education, and welfare, and other matters in which he has no interest.' (Good as Gold 122)

In short, the President is an egotist who takes no interest in government, and later it emerges that he spends much of his time napping. The ominous aspect of this emerges when Ralph reveals that his autobiography takes priority over running the country, and rather than calling for the book to be ghost-written, unelected advisors instead perform the tasks associated with the presidency. In Good as Gold, then, unelected bureaucrats have supplanted democracy, as the President is essentially a PR man, with his chosen officials actually governing the country. This makes it all the more absurd that the only criterion for their appointment is the ability to tow the party line.

35This explains much of the novel's (and Heller's own personal) antipathy towards Henry Kissinger. Kissinger was appointed as Secretary of State by Richard Nixon, and a significant amount of the novel's final pages emphasize that it was Kissinger "who could joke about brutalizing the Vietnamese with massive bombings as a face-saving gesture as we accepted their terms. It is he who could see no moral issues in the invasion of Cambodia. It is he who comes to embody the very nature of the power politics of the modern nation state" (Miller 9).And it is in the treatment of Kissinger that Heller abandons his rhetorical style and the use of irony and turns to pure parrhesia. Heller's personal feeling seems to bleed through the pages as he writes that Kissinger displayed "an arrogance and naïveté... that merited contempt" (Good as Gold 348). But typically, most of Heller's attention is not personal, but relates to Kissinger's role in the public sphere. He observes that "not once that Gold knew of had Kissinger raised a voice in protest against the fascistic use of police power to quell public opposition to the war in Southeast Asia" (Good as Gold 347). Here, Heller highlights Kissinger's immoral attitudes towards protesting citizens of the United States, demonstrating in clear language what he has elsewhere shown through the use of irony and verbal trickery: a system turned against its own people. Heller also describes Kissinger as surrounded by "a cloud of corruption," before also lambasting "the gaudy militarism of the portly trombenik [that] was more Germanic than Jewish" and 
comparing him with prominent Nazis, including Adolf Hitler (366). It is here, rather than in Catch-22, that the specter of fascism seems most vivid, and it is used to accuse Kissinger. A few pages on, Heller writes of Kissinger that "He was never altogether comfortable with Congress and was said to prefer a dictatorship without any parliamentary body to restrain him" (369), again showing his antipathy to democracy and the rule of law. Far from being a rhetorical device, an overstated comparison for effect, this criticism seems to be motivated by there being any similarity between Kissinger and the tactics of the Nazis, and the outrage at such a man being considered Jewish. Heller puts denunciations into the mouths of both Bruce Gold and his father: the latter splutters at the television while the younger Gold thinks that Kissinger "in all but the most confining definitions of cultural anthropology or bigotry, was no more Jewish, let's say, than Nelson Rockefeller, the prismatic apogee in a succession of patrons Kissinger had always managed to secure at pivotal moments in his career" (367).

36 Perhaps most telling of all, though, is the outrage at Kissinger's dishonesty. Heller writes that Kissinger "lied about peace and lied about war; he lied in Paris when he announced 'peace was at hand' just before the Presidential elections and he lied again afterward by blaming North Vietnam or bad faith when all his hondling went mechuleh" (Good as Gold 368). Again, Heller is more direct here than elsewhere, not dressing Kissinger's deceit in ironic wordplay but using the word "lied" repeatedly. However, these moments reveal the underlying targets elsewhere: because ultimately, it is dishonesty and manipulation that are the targets of Heller's irony in the first two novels. Catch-22-and, indeed, Catch-22 itself-is the most famous example of the way that Heller uses language to make clear how regulations are crafted to control, or the practices and logics employed by self-serving elites. Though Catch-22 is largely couched in allegory, and Something Happened is a novel still characterized by linguistic and structural complexity, by the time of Good as Gold Heller's ire has risen to the point that, in talking of Kissinger, he states outright that "he's so full of shit, that self-seeking schmuck" (Good as Gold 350). Given the development across the first three novels, Heller almost seems to be following the advice that the character Lieberman gives the protagonist just a few pages later: "well, why don't you just say it as simply as that?" (Good as Gold 353).

37 Heller's early novels, then, are all set in different environments, but what is common to them all is the attempt to reveal the destructive or illegitimate aspects of post-World War II social structures. "Heller chronicles the abuses... of systems so familiar, so logical in their illogic, that we accept the absurdities as normal" (Pinsker 8). When read alongside the later works of Foucault, we can understand this impulse in Heller as cynical in nature, and Heller's novels develop stylistically through this early period until reaching the point at which Heller speaks most directly. Though Heller would doubtless have struggled with some of the Cynic tenets (such as abjuring sexuality and wealth), the way in which Heller's blunt, direct satire dominates his novels suggests a compulsion to speak the truth for the good of society in the best spirit of parrhesia. Though there is a development in terms of stylistics across the three novels, consideration of this highlights that they are thematically homogeneous in one key respect, in that they all point towards the restrictive or repressive elements that administrative or corporate structures have on the individual spirit, whether that system is commercial or political in nature. They also tend to highlight the more oppressive power that underpins such systems and uses fear as a control mechanism. 
For Heller, as for his more aware protagonists, the logic of such systems appears absurd and is particularly ripe subject matter for the dark comedy so common to Heller's work in these early novels.

\section{BIBLIOGRAPHY}

Albrow, Martin. Bureaucracy. London: Pall Mall, 1970. Print.

Beer, Dan. Michel Foucault: Form and Power. Oxford: Legenda, 2002. Print.

Blau, Peter M. and Marshall W. Meyer. Bureaucracy in Modern Society. New York: Random House, 1971. Print.

Du Gay, Paul. In Praise of Bureaucracy: Weber, Organization, Ethics. London: Sage, 2000. Print.

Dumm, Thomas L. Michel Foucault and the Politics of Freedom. Oxford: Rowman and Littlefield, 2002. Print.

Elzioni-Halevy, Eva. Bureaucracy and Democracy: A Political Dilemma. London: Routledge and Kegan Paul, 1985. Print.

Fermaglich, Kirsten, “Mel Brooks' The Producers: Tracing American Jewish Culture Through Comedy, 1967-2007." American Studies 48.4 (2007): 59-87. Print.

Foucault, Michel. Fearless Speech. Ed. Joseph Pearson.Los Angeles: Semiotext(e), 2001. Print.

---. Politics, Philosophy Culture: Interviews and Other Writings. Ed. Lawrence D. Kritzman. Trans. Alan Sheridan. New York: Routledge, 2000. Print.

---. Power: Essential Works of Foucault 1954-1984. Ed. James D. Faubion. Trans. Robert Hurley et al. London: Penguin, 2000. Print.

Fowles, Anthony. Joseph Heller. London: Greenwich Exchange, 2005. Print.

Fried, Albert. McCarthyism: The Great American Red Scare. Oxford: Oxford University Press, 1997. Print.

Garrett, Leah. “Joseph Heller's Jewish War Novel Catch-22." Journal of Modern Jewish Studies 14.3 (2015): 391-408. Print.

Heller, Joseph. Catch-22. London: Corgi, 1981. Print.

---. Something Happened. London: Corgi, 1980. Print.

---. Good as Gold. London: Corgi, 1981. Print.

Heller, Joseph, and Sorkin, Adam J. Conversations with Joseph Heller. Jackson: University Press of Mississippi, 1993. Print.

Lansley, Stewart. After the Gold Rush. London: Random House, 1994. Print.

LeClair, Thomas. "Joseph Heller, Something Happened, and the Art of Excess." Studies in American Fiction, 9.2 (1981): 245-260. Print.

Massumi, Brian, ed. The Politics of Everyday Fear. Minneapolis: University of Minnesota, 1993. Print. 
Miller, Wayne C. "Ethnic Identity as Moral Focus: A Reading of Joseph Heller's Good as Gold." MELUS 6.3 (1979): 3-17. Web. 13 Apr 2016.

Moss, Jeremy, ed. The Later Foucault. London: Sage, 1998. Print.

Pinsker, Sanford. Understanding Joseph Heller. Columbia: University of South Carolina Press, 2009. Print.

Savil, Nikil. ‘Bartleby's All!'. Dissent, 61.4 (2014): 22-26. Web. 13 Apr 2016.

Searles, George J. “Something Happened: A New Direction for Joseph Heller.” Critique. 18.3 (1977):

74-82. Print.

Seed, David. The Fiction of Joseph Heller: Against the Grain. Basingstoke, Hampshire: MacMillan, 1989. Print.

Silberman, Bernard S. Cages of Reason: The Rise of the Rational State in France, Japan, the United States, and Great Britain. Chicago: University of Chicago Press, 1993. Print.

Sniderman, Stephen L. “'It Was All Yossarian's Fault': Power and Responsibility in Catch-22.” Twentieth Century Literature 19.4 (1973): 251-58. Print.

Stern, Frederick C. "Heller's Hell: Heller's later fiction, Jewishness and the Liberal Imagination." MELUS 15.4 (1988): 15-37. Print.

Strehle, Susan. “'A Permanent Game of Excuses': Determinism in Heller's Something Happened.” Modern Fiction Studies 24.4 (1978): 550-56. Web. 11 Apr 2016.

Thompson, Graham. Male Sexuality under Surveillance: The Office in American Literature. Iowa City: University of Iowa Press, 2003. Print.

\section{ABSTRACTS}

This article combines Foucault's exploration of the ancient Greek concept of parrhesia with the novels of Joseph Heller to attempt to arrive at a more complete critical position for an author whose work, aside from his first novel, is often critically neglected. The article explores the way in which Heller's writing progresses over his first three novels, becoming more explicit in its social critique. It also explores his uses dark humor-a popular device for comics, authors and filmmakers in the period-in his first three novels to preach against the way that American systems of a military, political, or corporate nature control the actions of supposedly free citizens, through intricate bureaucratic webs which border or tip into absurdism, and the fear which stems from the underlying covert threat to the citizen's wellbeing.

\section{INDEX}

Keywords: Catch-22, Good as Gold, Joseph Heller, Michel Foucault, parrhesia, Something Happened

\section{AUTHOR}

\section{PETER TEMPLETON}

Loughborough University 